\title{
A systematic literature review: how agile is agile project management?
}

\author{
Andy Behrens, Dakota State University,Andrew.behrens@dsu.edu \\ Martinson Ofori, Dakota State University, Martinson.ofori@trojans.dsu.edu \\ Cherie Noteboom, Dakota State University,Cherie.noteboom@dsu.edu \\ Dave Bishop, Dakota State University,Dave.Bishop@dsu.edu
}

\begin{abstract}
As disruptive technologies and innovations continue to develop, the resulting change forces organizations to consider adopting an agile mindset to move quickly. With an emphasis on an iterative and changing project approach characterized by daily reactivity, communication, and flexibility, the Agile Project Management (APM) approach is evolving to manage high uncertainty projects. A literature search was conducted on the following academic databases: ABI/Inform, ACM Digital Library, EBSCO Host, and IEEE Xplore. "Agile" and "project management" keywords were specified for the English language, peerreviewed articles published between January 2015 and March 2021 to answer the research question "How agile is agile project management?" The findings of the study provide contributions to research and practice on the state of evolution of APM.
\end{abstract}

Keywords: agile, agile project management, systematic literature review, agile software development, and traditional project management

\section{Introduction}

As disruptive technologies and innovations continue, the resulting change forces organizations to consider adopting an agile mindset (Project Management Institute \& Agile Alliance, 2017). Organizations adopting agile mindsets focus on an iterative and changing project approach characterized by daily reactivity, communication, and flexibility. In a business environment characterized by rapid change and increasing complexity, companies struggle to implement the strategies they need to generate and sustain a competitive advantage (Boston Consulting Group, 2016). Agility should not be seen as a lack of process; it provides the ability to adapt to diverse and unexpected situations (Santana Furtado Soares \& de Lemos Meira, 2015).

Agile Project Management (APM) is defined as an iterative approach that promotes customer inclusion, adjusts to change, and develops a working product (Project Management Institute \& Agile Alliance, 2017). This approach influences how high uncertainty projects which have high rates of change, complexity, and risk are managed. The aforementioned characteristics can present problems for the Traditional Project Management (TPM) approach. TPM is based on the sequential conception and is driven by fully defined requirements and deliverables (Project Management Institute, 2017a). The focus on the 'Iron Triangle Trap' identifies time, cost, and scope issues, but does not identify the additional analysis required to identify the issues (Wiboonrat, 2016). 


\section{Issues in Information Systems}

Volume 22, Issue 3, pp. 278-295, 2021

Consequently, as more definable work is automated, project teams are undertaking more high-uncertainty work projects that require agile methods (Sanchez et al., 2019). These methods explore feasibility in short cycles and quickly adapt based on evaluation and feedback. Therefore, the Agile Manifesto (http://agilemanifeso.org) was created and provides an approach for high uncertainty work. It utilizes the four values of 1.) Individuals and interactions over processes and tools, 2.) Working software over comprehensive documentation, 3.) Customer collaboration over contract negotiation, and 4.) Responding to change over following a plan (Project Management Institute \& Agile Alliance, 2017).

APM corresponds to a mindset driven by values and principles. Its popularity has increased due to its results on software quality and customer satisfaction. This has had an immediate impact on the job title of project managers. They exist on a significant number of agile projects, and they play the role of mentor, coordinator, negotiator, and process adapter (Shastri et al., 2021). Previous literature reviews have investigated improving business processes using an agile methodology (Schmitt \& Hörner, 2021), the comparison of agile and waterfall project management methodologies (Thesing et al., 2021), and the adoption drivers and critical success factors of agile project management (Noteboom et al., 2021). However, previous reviews did not address the agility of APM.

This study uses the four values of agile to classify the literature to discover whether APM is truly agile. Therefore, this study contributes to the body of knowledge on APM by offering guidance to project practitioners and researchers on the current state of agility by investigating the extant literature on 'How agile is Agile Project Management?' with comparison to the four Values of the Agile Manifesto. Theoretically, the study contributes to the evolution of APM to manage high-uncertainty projects by evaluating the literature for insight. The study also provides direction on the continued development of APM to support agile methods and high-uncertainty work for the practitioner. The study provides a theoretical background next, the research methodology is presented in the following section, the study results to follow, and a discussion of findings. The article will conclude with a summary of findings and implications for research and practice.

\section{Background}

The 14th Annual State of Agile Report (2020) reported the ability to manage changing priorities and project visibility as the top two capabilities of Agile implementation. However, there are still adoption challenges that continue to be related to organizational culture and resistance to change (14th Annual State of Agile Report, 2020). According to the report, the top reasons for adopting agile were accelerated software delivery, enhancing the ability to manage changing priorities, and increasing productivity. $84 \%$ of respondents indicated that they were below a high level of competency with Agile. This indicates an opportunity and the need for the improvement and development of APM.

Conboy (2009) provides a definition of agile that is widely cited, "the continual readiness of an information system development method to rapidly or inherently create change, proactively or reactively embrace change, and learn from change while contributing to perceived customer value (economy, quality, and simplicity), through its collective components and relationships with its environment." Organizations achieve greater agility through attention to people, processes, and culture (Project Management Institute, 2017b). In an agile approach, basic outcomes are defined, initial targets are established, and the project outcomes are consistently revisited and further refined using an adaptive process (Gemino et al., 2021). The traditional approach is defined by linear and predictable project planning practices designed to achieve a well-understood, achievable set of objectives (Gemino et al., 2021). There is also a third approach defined as a hybrid approach that combines both traditional and agile practices as described above (Gemino et al., 2021). 


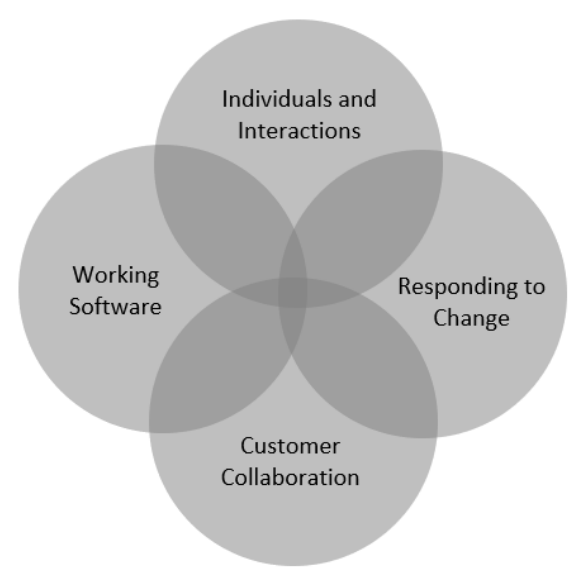

Figure 1: Four values of APM agility

The Agile Manifesto and mindset have four values: Individuals and interactions over processes and tools; Working software over comprehensive documentation; Customer collaboration over contract negotiation, and Responding to change over following a plan (Project Management Institute \& Agile Alliance, 2017). The bolded areas are valued over the other items. The values shown in Figure 1 will be used to classify the literature.

\section{Methodology}

This review employs the software engineering guidelines for performing and reporting systematic literature reviews (SLRs). The guidelines, as proposed by Kitchenham and Charters (2007), are a common method for conducting SLRs in software engineering and IS research. It offers a standardized and replicable approach to evaluating and interpreting extant literature pertaining to the research question. The current review uses this approach to summarize existing literature to identify the current position and gaps on agile as a project management methodology. The ensuing section describes the three main phases of the current review in accordance with the guidelines: planning, conducting, and reporting the study.

\section{Review Planning}

This process involves identifying the need for the review, commissioning the review, and specifying the research question. The introduction and background sections establish these components.

\section{Conducting the Review}

The activities in this section include identifying the research, selecting the primary studies, performing quality assessment, as well as extracting and synthesizing the information from the selected studies.

\section{Research identification}

Following the formulation of the research questions, the current following search query was developed to gather relevant literature from ABI/Inform, ACM Digital Library, EBSCO Host, and IEEE Xplore databases: "Agile" AND "Project Management". In collating the relevant articles for the review, English language articles published in journals, books, or conference papers between January 2015 and March 2021 were sourced for the four values of the agile manifesto. 


\section{Issues in Information Systems}

Volume 22, Issue 3, pp. 278-295, 2021

\section{Study Selection and Quality}

Using a predefined strategy established by all four authors, two authors assessed the titles and abstracts by independently evaluating a randomly selected study sample for inclusion or exclusion. This resulted in an $87.76 \%$ rate of agreement and a Cohen's kappa (Cohen, 2016) of 0.75, which represented substantial agreement. The full text of the selected studies was then consulted for the four values of the agile manifesto. The consensus method was used to solve any disagreements between the two researchers. Where a suitable compromise could not be achieved, all four authors discussed the merits of the study with reference to the study objective.

\section{Data Extraction and Synthesis}

An Excel sheet was created for extracting and synthesizing the literature. This assisted in reducing the chance of bias in the report. The data collected from each study included the title, publication avenue, study design, publication year, objectives, and the exact information relating to each of the four values. A summary of the data collected is presented in Table 1 . The following section describes the results of the review which is the last activity specified by the SLR reporting guideline adapted from Kitchenham \& Charters (2007).

\section{Results}

\section{Study Selection}

The identification process resulted in the selection of 376 records from the initial electronic database search. Duplicate records (36) were removed and 340 records were moved to the screening process. The exclusion criteria removed 235 records and 105 records met eligibility criteria for full record review. An additional 36 records were excluded during the full article review and 69 records were included for analysis in the study. A summary of search and study selection results is presented in Figure 2. 


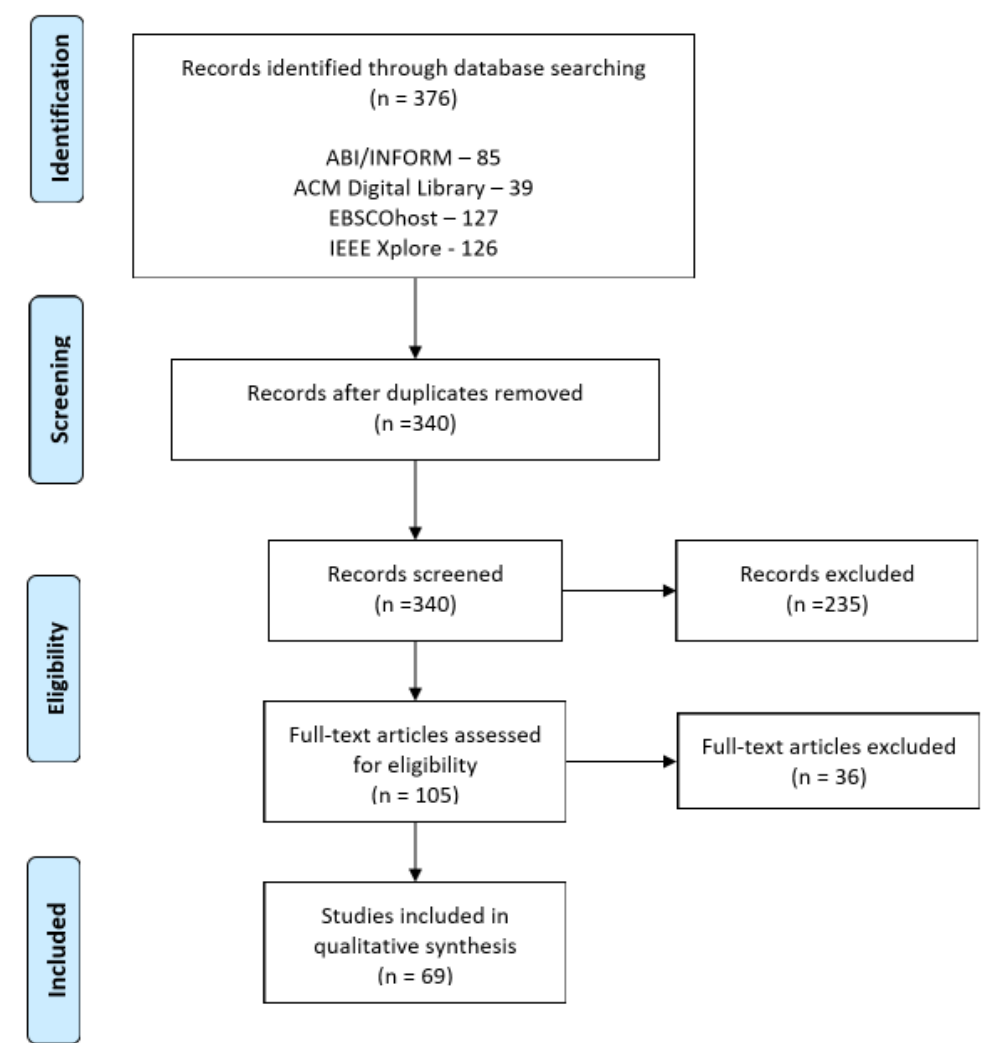

Figure 2: PRISMA flow chart for study selection

\section{Publication Statistics}

The APM paper distribution by year indicates peaks and valleys during the collection periods. The low occurrence of publications was in 2018 with six. The peak number of 16 articles occurred in 2019. As displayed in Figure 3, there does not appear to be a trend in the number of publications per year. Figure 4 demonstrates the publication statistics by type of publication. Journal articles account for $68 \%$ of the publications and peer-reviewed conference papers comprise $27.5 \%$ of the included results.

Case study and survey research were the most frequently mentioned study design components. The included articles provided insight into a variety of investigative approaches to understanding APM as shown in Figure 5.

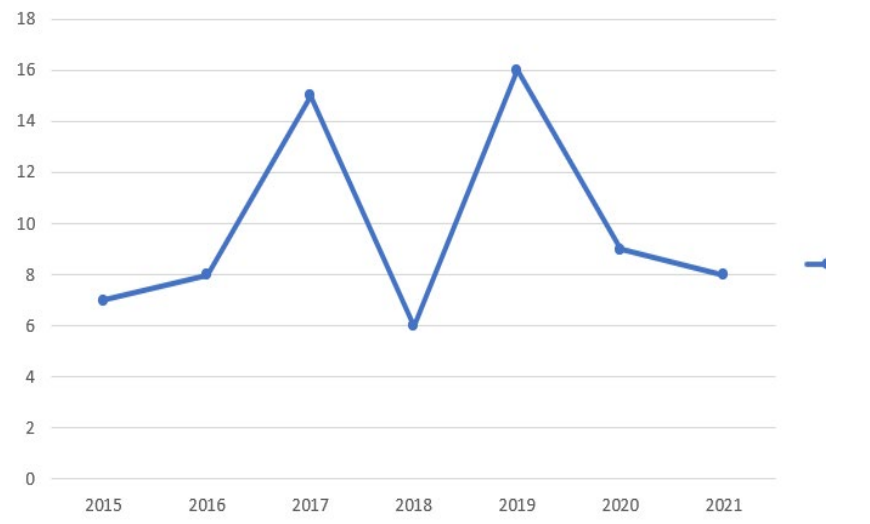

Figure 3: Included publication by year

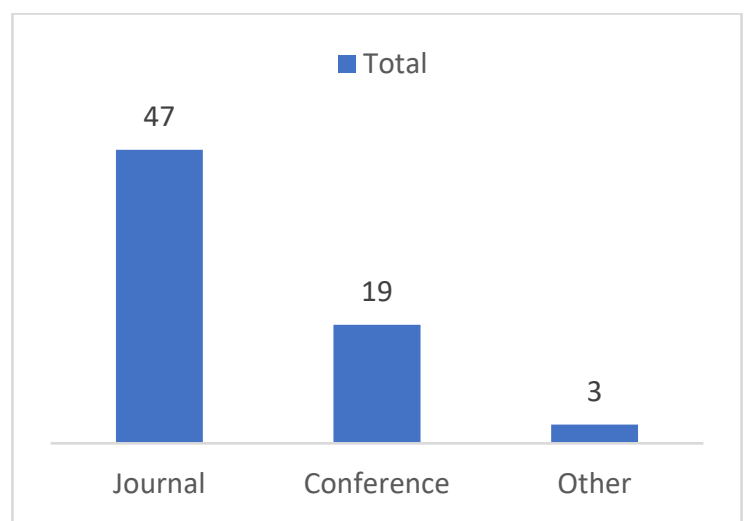

Figure 4: Included publication by type 


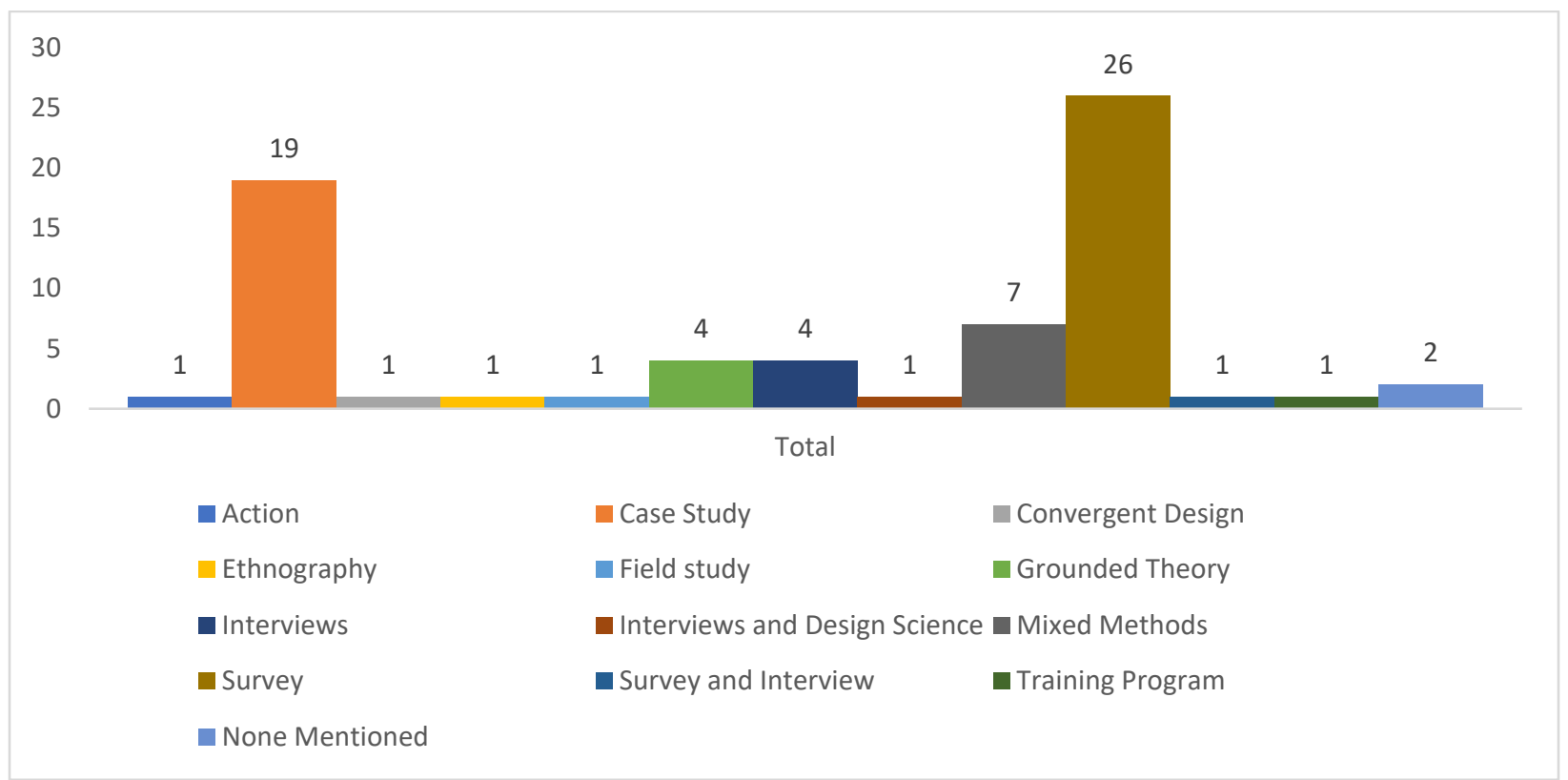

Figure 5: Study design of included publications

The articles that discussed APM were the highest at $74 \%$. There were much fewer articles discussing a hybrid PM approach at 25\%. These statistics are shown in Figure 6.

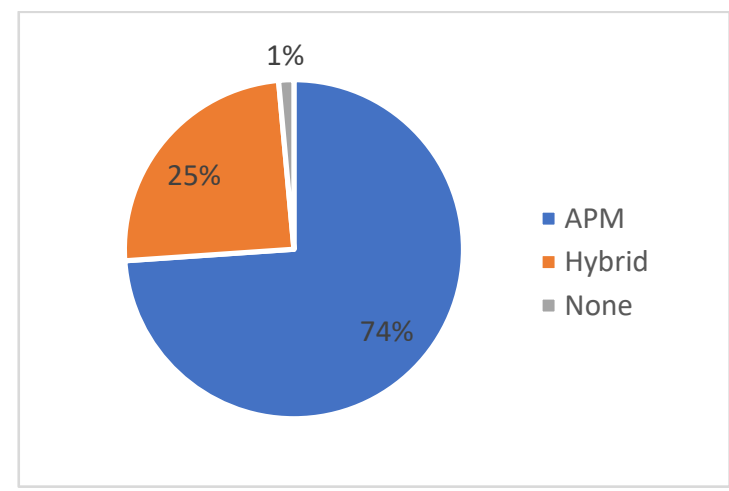

\section{Figure 6: Percentage of PM approaches used in included articles}

Table 1 lists the fully categorized articles with their respective PM style, and which agile value they have met. All articles listed below were the included articles of our study. The citations list the authors and the year each article was published. The PM style discusses which type of approach each author studied. The following four columns focus on whether each article met one or more of the four agile values. Each $\mathrm{x}$ details whether that value was met in the study. At the bottom of Table 1, the count of each agile value is displayed. 
Issues in Information Systems

Volume 22, Issue 3, pp. 278-295, 2021

Table 1: Study design of included publications

\begin{tabular}{|c|c|c|c|c|c|}
\hline Citation & $\begin{array}{l}\text { PM } \\
\text { Style }\end{array}$ & $\begin{array}{c}\text { Interactions and } \\
\text { Individuals }\end{array}$ & $\begin{array}{l}\text { Working } \\
\text { Software }\end{array}$ & $\begin{array}{c}\text { Customer } \\
\text { Collaboration }\end{array}$ & $\begin{array}{c}\text { Response to } \\
\text { Change }\end{array}$ \\
\hline (Sanchez et al., 2019) & Hybrid & $\mathrm{x}$ & & $\mathrm{x}$ & $\mathrm{x}$ \\
\hline (Andrei et al., 2019) & Hybrid & $\mathrm{x}$ & $\mathrm{x}$ & & $\mathrm{x}$ \\
\hline (Şarlak, 2020) & APM & $\mathrm{x}$ & $\mathrm{x}$ & $\mathrm{x}$ & $\mathrm{x}$ \\
\hline (Stormi et al., 2019) & APM & $\mathrm{x}$ & $\mathrm{x}$ & $\mathrm{x}$ & $\mathrm{x}$ \\
\hline (Gemino et al., 2021) & Hybrid & $\mathrm{x}$ & $\mathrm{x}$ & $\mathrm{x}$ & $\mathrm{x}$ \\
\hline (Lill et al., 2020) & APM & $\mathrm{x}$ & $\mathrm{x}$ & $\mathrm{x}$ & $\mathrm{x}$ \\
\hline (Salman et al., 2021) & APM & $\mathrm{x}$ & $\mathrm{x}$ & $\mathrm{x}$ & \\
\hline (Khomyakov et al., 2020) & APM & $\mathrm{x}$ & $\mathrm{x}$ & $\mathrm{x}$ & $\mathrm{x}$ \\
\hline (Perlak, 2019) & APM & $\mathrm{x}$ & & & $\mathrm{x}$ \\
\hline (Mkoba \& Marnewick, 2020) & APM & $\mathrm{x}$ & $\mathrm{x}$ & $\mathrm{x}$ & $\mathrm{x}$ \\
\hline (Luong et al., 2021) & APM & $\mathrm{x}$ & & $\mathrm{x}$ & \\
\hline (Bhatnagar \& Grosse, 2019) & APM & $\mathrm{x}$ & $\mathrm{x}$ & $\mathrm{x}$ & $\mathrm{x}$ \\
\hline (Pareliya, 2019) & APM & $\mathrm{x}$ & $\mathrm{x}$ & $\mathrm{x}$ & $\mathrm{x}$ \\
\hline (Olteanu, 2018) & APM & $\mathrm{x}$ & $\mathrm{x}$ & $\mathrm{x}$ & $\mathrm{x}$ \\
\hline (Fitriani et al., 2021) & APM & $\mathrm{x}$ & $\mathrm{x}$ & $\mathrm{x}$ & $\mathrm{x}$ \\
\hline (Zasa et al., 2021) & Hybrid & $\mathrm{x}$ & $\mathrm{x}$ & $\mathrm{x}$ & $\mathrm{x}$ \\
\hline (Hussien et al., 2019) & APM & $\mathrm{x}$ & & $\mathrm{x}$ & $\mathrm{x}$ \\
\hline (Kurniawan, Adler, et al., 2020) & APM & $\mathrm{x}$ & $\mathrm{x}$ & $\mathrm{x}$ & \\
\hline (Marinho et al., 2019) & Hybrid & $\mathrm{x}$ & $\mathrm{x}$ & $\mathrm{x}$ & $\mathrm{x}$ \\
\hline (Ismat Soueid \& Corá Martins, 2021) & APM & $\mathrm{x}$ & $\mathrm{x}$ & $\mathrm{x}$ & $\mathrm{x}$ \\
\hline (Ereiz \& Mušić, 2019) & APM & $\mathrm{x}$ & $\mathrm{x}$ & $\mathrm{x}$ & $\mathrm{x}$ \\
\hline (Kerscher \& Günzel, 2019) & APM & $\mathrm{x}$ & & $\mathrm{x}$ & $\mathrm{x}$ \\
\hline (Kurniawan, Budiastuti, et al., 2020) & APM & $\mathrm{x}$ & $\mathrm{x}$ & $\mathrm{x}$ & $\mathrm{x}$ \\
\hline (Hayat et al., 2019) & APM & $\mathrm{x}$ & & & $\mathrm{x}$ \\
\hline (Copola Azenha Flávio et al., 2021) & Hybrid & $\mathrm{x}$ & $\mathrm{x}$ & $\mathrm{x}$ & $\mathrm{x}$ \\
\hline (Thorgren \& Caiman, 2019) & APM & & & & \\
\hline (Vahanvati \& Mulligan, 2017) & Hybrid & & & & \\
\hline (Pool et al., 2019) & APM & $\mathrm{x}$ & & $\mathrm{x}$ & $\mathrm{x}$ \\
\hline (Lei et al., 2017) & APM & & & & \\
\hline (Jørgensen, 2016) & None & $\mathrm{x}$ & & $\mathrm{x}$ & \\
\hline (Gaudenzi \& Christopher, 2016) & APM & & & & $\mathrm{x}$ \\
\hline (Batra, 2017) & Hybrid & & $\mathrm{x}$ & $\mathrm{x}$ & $\mathrm{x}$ \\
\hline (Taylor, 2016) & Hybrid & $\mathrm{x}$ & & & \\
\hline (Gheorghe et al., 2017) & Hybrid & & & & $\mathrm{x}$ \\
\hline (Higuchi \& Nakano, 2017) & Hybrid & $\mathrm{x}$ & & $\mathrm{x}$ & \\
\hline (Alsari et al., 2020) & Hybrid & $\mathrm{x}$ & $\mathrm{x}$ & $\mathrm{x}$ & $\mathrm{x}$ \\
\hline (Hobbs \& Petit, 2017) & APM & $\mathrm{x}$ & $\mathrm{x}$ & $\mathrm{x}$ & \\
\hline (Mirzaei \& Mabin, 2017) & Hybrid & & & $\mathrm{x}$ & \\
\hline (Conforto \& Amaral, 2016) & Hybrid & $\mathrm{x}$ & & $\mathrm{x}$ & $\mathrm{x}$ \\
\hline (Azanha et al., 2017) & APM & $\mathrm{x}$ & $\mathrm{x}$ & $\mathrm{x}$ & $\mathrm{x}$ \\
\hline
\end{tabular}




\section{Issues in Information Systems}

Volume 22, Issue 3, pp. 278-295, 2021

\begin{tabular}{|c|c|c|c|c|c|}
\hline (Paterek, 2019) & APM & $\mathrm{x}$ & & $\mathrm{x}$ & \\
\hline (Cooper \& Sommer, 2018) & Hybrid & $\mathrm{x}$ & $\mathrm{x}$ & $\mathrm{x}$ & $\mathrm{x}$ \\
\hline (Baham et al., 2017) & APM & $\mathrm{x}$ & $\mathrm{x}$ & $\mathrm{x}$ & $\mathrm{x}$ \\
\hline (Kassab et al., 2018) & APM & $\mathrm{x}$ & $\mathrm{x}$ & $\mathrm{x}$ & \\
\hline (Nerurkar \& Das, 2017) & APM & $\mathrm{x}$ & $\mathrm{x}$ & $\mathrm{x}$ & $\mathrm{x}$ \\
\hline (Wiboonrat, 2016) & APM & $\mathrm{x}$ & $\mathrm{x}$ & $\mathrm{x}$ & $\mathrm{x}$ \\
\hline (Salaou et al., 2021) & APM & $\mathrm{x}$ & $\mathrm{x}$ & $\mathrm{x}$ & $\mathrm{x}$ \\
\hline (Lehnen et al., 2016) & APM & $\mathrm{x}$ & $\mathrm{x}$ & $\mathrm{x}$ & $\mathrm{x}$ \\
\hline (Dingsøyr et al., 2018) & APM & $\mathrm{x}$ & $\mathrm{x}$ & $\mathrm{x}$ & $\mathrm{x}$ \\
\hline (Serrador \& Pinto, 2015) & APM & $\mathrm{x}$ & $\mathrm{x}$ & $\mathrm{x}$ & $\mathrm{x}$ \\
\hline (Meding, 2017) & APM & $\mathrm{x}$ & $\mathrm{x}$ & $\mathrm{x}$ & $\mathrm{x}$ \\
\hline (Siddique \& Hussein, 2019) & APM & $\mathrm{x}$ & $\mathrm{x}$ & $\mathrm{x}$ & $\mathrm{x}$ \\
\hline (Cvetković et al., 2017) & APM & $\mathrm{x}$ & $\mathrm{x}$ & $\mathrm{x}$ & $\mathrm{x}$ \\
\hline (Friess, 2018) & APM & $\mathrm{x}$ & & & \\
\hline (Zhang et al., 2020) & APM & $\mathrm{x}$ & $\mathrm{x}$ & $\mathrm{x}$ & $\mathrm{x}$ \\
\hline (Sievi-Korte et al., 2015) & APM & $\mathrm{x}$ & & & $\mathrm{x}$ \\
\hline (Siddique \& Hussein, 2016) & Hybrid & & & $\mathrm{x}$ & \\
\hline (Hoda \& Murugesan, 2016) & APM & $\mathrm{x}$ & $\mathrm{x}$ & & $\mathrm{x}$ \\
\hline (Mishra et al., 2017) & APM & & $\mathrm{x}$ & & $\mathrm{x}$ \\
\hline (Tanner \& Mackinnon, 2015) & APM & $\mathrm{x}$ & $\mathrm{x}$ & $\mathrm{x}$ & $\mathrm{x}$ \\
\hline (Lindsjørn et al., 2016) & APM & $\mathrm{x}$ & & & \\
\hline (Sampietro, 2016) & APM & $\mathrm{x}$ & $\mathrm{x}$ & $\mathrm{x}$ & $\mathrm{x}$ \\
\hline (Wells et al., 2015) & APM & $\mathrm{x}$ & $\mathrm{x}$ & $\mathrm{x}$ & $\mathrm{x}$ \\
\hline (Gablas et al., 2018) & APM & & & & $\mathrm{x}$ \\
\hline (Kaczorowska, 2015) & APM & $\mathrm{x}$ & $\mathrm{x}$ & $\mathrm{x}$ & $\mathrm{x}$ \\
\hline (Shastri et al., 2017) & Hybrid & $\mathrm{x}$ & $\mathrm{x}$ & $\mathrm{x}$ & $\mathrm{x}$ \\
\hline (Alahyari et al., 2018) & APM & $\mathrm{x}$ & $\mathrm{x}$ & $\mathrm{x}$ & $\mathrm{x}$ \\
\hline (Koch \& Schermuly, 2020) & APM & $\mathrm{x}$ & $\mathrm{x}$ & $\mathrm{x}$ & $\mathrm{x}$ \\
\hline (Law \& Lárusdóttir, 2015) & APM & $\mathrm{x}$ & $\mathrm{x}$ & $\mathrm{x}$ & $\mathrm{x}$ \\
\hline \multicolumn{2}{|c|}{ Count of the Four Agile Values: } & 59 & 46 & 54 & 53 \\
\hline
\end{tabular}

\section{Discussion}

To answer our research question, how agile is agile project management? Our study indicates APM is agile as defined by the classification scheme shown in Figure 1. The four values of APM agility were present in 38 of the 69 articles. 11 articles contained three of the values and 13 articles referenced two of the values. One value was present in eight articles and one article failed to mention any value. In the following section, we discuss the findings on APM agility from the literature review with a discussion on each value. 


\section{Issues in Information Systems}

Volume 22, Issue 3, pp. 278-295, 2021

\section{APM Agile Values}

\section{Individuals and Interactions}

The role of the project manager in APM is servant leadership which focuses on coaching anyone who needs assistance, fostering collaboration, and aligning stakeholder needs (Project Management Institute \& Agile Alliance, 2017). This leadership enables a more in-depth focus on individuals and interactions that results in a greater flow of values (Copola Azenha Flávio et al., 2021; Fitriani et al., 2021; Olteanu, 2018), emphasis on rapid feature delivery to the customer (Nerurkar \& Das, 2017; Pool et al., 2019) and self-managed teams (Serrador \& Pinto, 2015). The role of the project manager also extends to APM and the interactions and individuals of the teams. It was found in teams to also improve collaboration, communication, team dynamics, iterative planning, and multiple releases of usable projects (Pool et al., 2019). Serrador \& Pinto (2015) also found that neither the project complexity nor experience of the project team limited the project success.

However, there are areas for improvement for APM. A trade-off between the short-term benefit of rapid delivery and an increase in unplanned technical debt from quick agile responses may result in major consequences if that the debt is forgotten and grows up to become a liability for the system maintainability and scalability (Salaou et al., 2021). This also can cause teams to focus less on tools and processes. This can consequently cause teams to neglect or minimize the importance of documentation.

\section{Responding to Change}

This systematic literature review suggested that $77 \%$ of research projects used adaptiveness to change in their studies. Companies are faced with spontaneous market changes and they often have to shorten the software product delivery and be more responsive to the customers' demands (Olteanu, 2018). Customer's changing opinions on features increase the cost of updating artifacts under TPM and the impact on each phase of the project as well as drive down customer satisfaction (Andrei et al., 2019). Understanding and being adaptive to change enables managing agile projects more effectively and allowing for flexible requirements. An exploratory study was completed by Pareilya (2019) showing that $41 \%$ of agile users thought being adaptive to change was extremely important. $45 \%$ claimed in the Pareilya study that adaptiveness to change is very important. In sum, $86 \%$ of the users thought that being adaptive to change is important. $76.8 \%$ of the articles reviewed in this study implemented the response to change principle.

Adapting to change as an agility principle enables project management teams to react to or mitigate risks that may cause going over budget, delays in implementation, and producing a different solution than expected (Kaczorowska, 2015; Serrador \& Pinto, 2015). In most cases, being adaptive to change helps mitigate many barriers associated with the traditional project management style. For example, a project team could benefit from continuous discussion (Andrei et al., 2019), maintain flow during the transformation process (Fitriani et al., 2021), and understanding the importance of an agile project manager (Hoda \& Murugesan, 2016).

One of the key areas that responding to change comes into play is in regard to requirements. Agility is defined by adapting to new conditions (Şarlak, 2020). Agile is a preferred approach when project stakeholders expect significant changes in requirements (Gemino et al., 2021). Requirements change in Performance Management Systems, like all systems, is inevitable, and agile is a methodological way to respond to that change (Stormi et al., 2019). Another key to responding to change identified by Stormi, Lain \& Korhonen (2019) is adopting iterative and incremental work practices which support resilience in the face of dynamic requirements. Finally, Gemino et al. (2021) point out that the team attitude toward change is an important success indicator for projects embracing agile practices. 


\section{Issues in Information Systems}

Volume 22, Issue 3, pp. 278-295, 2021

\section{Customer Collaboration}

Law and Larusdottir (2015) summarize the definition of a customer as someone, company, or individual that receives a product or service. Khomyakov et al. (2020) note that both plan-based and agile organizations place a high priority on customer collaboration and customer satisfaction. In agile practices, such as Scrum, the Product Owner is the representative of the customer and may pull in customers as needed throughout the life of the project (Schwaber \& Sutherland, 2011). Shastri et al. (2017) describe the traditional project manager's role with customers as one of negotiating requirements. Consequently, in a hybrid approach, to gain the maximum benefit, it will be necessary to expand the traditional role to enhance customer collaboration.

\section{Working Software}

Generally, it is accepted that APM evolved from software development practices and is predicated upon incremental product delivery which grew from a rising need for faster yet adaptable software release cycles (Highsmith \& Cockburn, 2001). Rather than the top-heavy comprehensive documentation that characterizes traditional project management, Zhang et al., (2020) found that reduced communication overheads, increased concurrency, and increased personal ability created the right conditions for small self-organizing teams to realize increased productivity and innovation towards systems creation. This effect was not limited to small-scale software development teams. In large multiteam development where documentation is generally required and advised, the literature demonstrated that upfront documentation came in the form of intra- and cross-team expectations written in wikis. Additional documentation during and at the end of the project was ensured through the iterative unit, functional, and integration tests (Marinho et al., 2019). Further, progress towards working software was often achieved through multi-level coordination of resources from impersonal modes, such as through instant messaging, to group modes, such as scrum of scrums and frequent demos (Dingsøyr et al., 2018; Hobbs \& Petit, 2017; Sievi-Korte et al., 2015).

Instinctively, APM as a project management practice is popular in software development cycles. The current study found that in the context of APM, the idea of working software over comprehensive documentation - as enshrined in the Agile Manifesto - transcends its literal meaning. Several studies found ways to implement APM outside of software development cycles. Mirzaei \& Mabin (2017) demonstrated that achieving cadence and delivering incremental value through APM was viable for public sector policy development. The current study found several such applications of APM resulted in the iterative delivery of "working software" in various non-software industries such as real estate, electrical engineering, and even disaster management (Baham et al., 2017; Fitriani et al., 2021; Gheorghe et al., 2017; Pareliya, 2019; Vahanvati \& Mulligan, 2017). From APM's starting point in 2001, there has been constant hope and support for the move to agility. As the pace of technology adoption continues to increase, the need to respond quickly becomes paramount. APM will continue to evolve to meet additional demand.

\section{Limitations}

One of the limitations of this research is that more breadth than depth was covered. This study considered four agile values that are broad in nature. There are twelve principles of agile studies that could be applied to a similar research project to get a more in-depth view of the current state of research. We also cannot claim that this was an exhaustive search of research articles. The coding of the results from the literature as system reviews is also threatened by misclassification. This was minimized by having two authors code the studies with input from the other two authors to resolve any issues with the classification. Another limitation is the use of academic subscription databases as our only source. Since APM is practical, including only peer-reviewed articles may have unintentionally biased this study toward the academic settings by ignoring periodicals and professional publications such as PMI. 


\section{Issues in Information Systems}

Volume 22, Issue 3, pp. 278-295, 2021

Although $74 \%$ of articles were classified as agile we do recognize that some papers and studies were single value-focused. Although they do not touch on all four values, we felt they contributed to the agility of APM overall.

\section{Conclusion and Future Research}

As technology innovation is expected to accelerate, our study investigated the literature to determine how agile is APM? The evidence shows that APM is making strides towards becoming agile. There is still some work to do before APM becomes truly agile. Authors must continue to address agility using the four principles to ensure they are using APM and not claiming agility through a hybrid style. The study analyzed and evaluated 69 articles to assess the agility of APM as measured by the existence of the four agile values. The need for APM to continue to evolve and contribute to the success of high-uncertainty work will continue to grow.

Future research could focus on a more in-depth review of the twelve principles of agile studies. This would provide a more granular view on APM research to analyze how rigorous the agile methodology is being applied. Researchers could also conduct a qualitative or quantitative study on APM implementing the four values. From a qualitative perspective, a researcher could better understand APM and its application in information systems projects. A quantitative study could analyze relationships and investigate how each value could impact project success in an agile information systems project. Further, a framework could be developed by researchers to guide project management practitioners to make sure they are addressing each agile value when applying an agile methodology. Finally, researchers could investigate ways to optimize APM for high-uncertainty work within high-growth technologies. Examples include but are not limited to artificial intelligence, cloud technologies, big data, and analytics.

\section{References}

14th Annual State of Agile Report. (2020). Digital.AI.

Alahyari, H., Horkoff, J., Matsson, O., \& Egenvall, K. (2018). What Do Agile Teams Find Important for Their Success? 2018 25th Asia-Pacific Software Engineering Conference (APSEC), 474-483. https://doi.org/10.1109/APSEC.2018.00062

Alsari, A., Qureshi, R., \& Algarni, A. (2020). Agile Framework To Transform Traditional Team. 2020 IEEE Frontiers in Education Conference (FIE), 1-9. https://doi.org/10.1109/FIE44824.2020.9274240

Andrei, B.-A., Casu-Pop, A.-C., Gheorghe, S.-C., \& Boiangiu, C.-A. (2019). A Study On Using Waterfall And Agile Methods In Software Project Management. Journal of Information Systems \& Operations Management, 125-135. ABI/INFORM Collection.

Azanha, A., Ana Rita Tiradentes Terra Argoud, João Batista de Camargo Junior, \& Pedro Domingos Antoniolli. (2017). Agile project management with Scrum. International Journal of Managing Projects in Business, 10(1), 121-142. ABI/INFORM Collection. https://doi.org/10.1108/IJMPB06-2016-0054

Baham, C., Hirschheim, R., Calderon, A. A., \& Kisekka, V. (2017). An Agile Methodology for the Disaster Recovery of Information Systems Under Catastrophic Scenarios. Journal of Management Information Systems, 34(3), 633-663. EBSCO MegaFILE. 


\section{Issues in Information Systems}

Volume 22, Issue 3, pp. 278-295, 2021

Batra, D. (2017). Adapting Agile Practices for Data Warehousing, Business Intelligence, and Analytics. Journal of Database Management, 28(4), 1. ABI/INFORM Collection.

Bhatnagar, S., \& Grosse, M. (2019). Future workplace organisation: How digitisation affects employees' job satisfaction in agile workplaces. International Journal of Product Development, 23(4), 264 291. ABI/INFORM Collection. https://doi.org/10.1504/IJPD.2019.105492

Boston Consulting Group. (2016). Connecting Business Strategy and Project Management. Project Management Institute, 16.

Cohen, J. (2016). A Coefficient of Agreement for Nominal Scales: Educational and Psychological Measurement. https://doi.org/10.1177/001316446002000104

Conboy, K. (2009). Agility from First Principles: Reconstructing the Concept of Agility in Information Systems Development. Information Systems Research, 20(3), 329-354. https://doi.org/10.1287/isre.1090.0236

Conforto, E. C., \& Amaral, D. C. (2016). Agile project management and stage-gate model-A hybrid framework for technology-based companies: JET-M JET-M. Journal of Engineering and Technology Management, 40, 1. ABI/INFORM Collection.

Cooper, R. G., \& Sommer, A. F. (2018). Agile-Stage-Gate for Manufacturers. Research Technology Management, 61(2), 17-26. EBSCO MegaFILE.

Copola Azenha Flávio, Aparecida Reis Diane, \& Leme Fleury André. (2021). The Role and Characteristics of Hybrid Approaches to Project Management in the Development of Technology-Based Products and Services. Project Management Journal, 52(1), 90-110. ABI/INFORM Collection. https://doi.org/10.1177/8756972820956884

Cvetković, N., Morača, S., Jovanović, M., Medojević, M., \& Lalić, B. (2017). Enhancing the Agility and Performances of a Project with Lean Manufacturing Practices. Annals of DAAAM \& Proceedings, 28, 661-670. Academic Search Premier.

Dingsøyr, T., Moe, N. B., \& Seim, E. A. (2018). Coordinating Knowledge Work in Multiteam Programs: Findings From a Large-Scale Agile Development Program. Project Management Journal, 49(6), 64-77. EBSCO MegaFILE.

Ereiz, Z., \& Mušić, D. (2019). Scrum Without a Scrum Master. 2019 IEEE International Conference on Computer Science and Educational Informatization (CSEI), 325-328. https://doi.org/10.1109/CSEI47661.2019.8938877

Fitriani, A. N., Raharjo, T., Hardian, B., \& Prasetyo, A. (2021). IT Infrastructure Agile Adoption for SDWAN Project Implementation in Pharmaceutical Industry: Case Study of an Indonesian Company. 2021 IEEE International IOT, Electronics and Mechatronics Conference (IEMTRONICS), 1-6. https://doi.org/10.1109/IEMTRONICS52119.2021.9422650

Friess, E. (2018). "Filling to Capacity": An Exploratory Study of Project Management Language in Agile Scrum Teams. Technical Communication, 65(2), 169-180. Education Database; Research Library. 


\section{Issues in Information Systems}

Volume 22, Issue 3, pp. 278-295, 2021

Gablas, B., Ruzicky, E., \& Ondrouchova, M. (2018). The Change in Management Style during then Course of a Project from the Classical to the Agile Approach. Journal of Competitiveness, 10(4), 38-53. ABI/INFORM Collection. https://doi.org/10.7441/joc.2018.04.03

Gaudenzi, B., \& Christopher, M. (2016). Achieving supply chain 'Leagility' through a project management orientation. International Journal of Logistics: Research \& Applications, 19(1), 3-18. EBSCO MegaFILE. https://doi.org/10.1080/13675567.2015.1073234

Gemino, A., Horner Reich Blaize, \& Serrador, P. M. (2021). Agile, Traditional, and Hybrid Approaches to Project Success: Is Hybrid a Poor Second Choice? Project Management Journal, 52(2), 161-175. ABI/INFORM Collection. https://doi.org/10.1177/8756972820973082

Gheorghe, C. M., Greculescu, A., \& Melcescu, L. M. (2017). Agile Approach in Electrical Engineering. Research Impact and Outcomes. Conference on Economic and Social Development, 486-494. ABI/INFORM Collection http://www.ezproxy.dsu.edu:2048/login?url=https://search.proquest.com/docview/2071305041?a ccountid $=27073$

Hayat, F., Rehman, A. U., Arif, K. S., Wahab, K., \& Abbas, M. (2019). The Influence of Agile Methodology (Scrum) on Software Project Management. 2019 20th IEEE/ACIS International Conference on Software Engineering, Artificial Intelligence, Networking and Parallel/Distributed Computing (SNPD), 145-149. https://doi.org/10.1109/SNPD.2019.8935813

Highsmith, J., \& Cockburn, A. (2001). Agile software development: The business of innovation. Computer, 34(9), 120-127. https://doi.org/10.1109/2.947100

Higuchi, M. M., \& Nakano, D. N. (2017). Agile Design: A Combined Model Based On Design Thinking And Agile Methodologies For Digital Games Projects. Revista de Gestão e Projetos, 8(2), 109126. ABI/INFORM Collection; Research Library.

Hobbs, B., \& Petit, Y. (2017). Agile Methods on Large Projects in Large Organizations. Project Management Journal, 48(3), 3-19. EBSCO MegaFILE. https://doi.org/10.1177/875697281704800301

Hoda, R., \& Murugesan, L. K. (2016). Multi-level agile project management challenges: A self-organizing team perspective. The Journal of Systems and Software, 117, 245. ABI/INFORM Collection. https://doi.org/10.1016/j.jss.2016.02.049

Hussien, A., Tucker, M., Cotgrave, A., Al-Khafajiy, M., \& Shamsa, T. B. (2019). Optimizing Project Delivery through Augmented Reality and Agile Methodologies. 2019 12th International Conference on Developments in ESystems Engineering (DeSE), 1006-1013. https://doi.org/10.1109/DeSE.2019.00187

Ismat Soueid, M., \& Corá Martins, A. F. (2021). SCRUM AND AGILITY BEYOND IT: EVIDENCES IN THE BRAZILIAN MINING INDUSTRY. Revista de Gestão e Projetos, 12(1), 123-148.

Jørgensen, M. (2016). A survey on the characteristics of projects with success in delivering client benefits. Information and Software Technology, 78, 83. ABI/INFORM Collection. 


\section{Issues in Information Systems}

Volume 22, Issue 3, pp. 278-295, 2021

Kaczorowska, A. (2015). Traditional and agile project management in public sector and ICT. 2015 Federated Conference on Computer Science and Information Systems (FedCSIS), 1521-1531. https://doi.org/10.15439/2015F279

Kassab, M., DeFranco, J., \& Graciano Neto, V. (2018). An Empirical Investigation on the Satisfaction Levels with the Requirements Engineering Practices: Agile vs. Waterfall. 2018 IEEE International Professional Communication Conference (ProComm), 118-124. https://doi.org/10.1109/ProComm.2018.00033

Kerscher, S., \& Günzel, H. (2019). SCRUM4CONSULTING - AGILE PROJECT MANAGEMENT FOR CONSULTING PROJECTS. Project Management Development - Practice \& Perspectives, 242 253. Business Source Premier.

Khomyakov, I., Mirgalimova, R., \& Sillitti, A. (2020). An Investigation of the Project Management Approaches of Agile and Plan-Based Companies. Proceedings of the 35th Annual ACM Symposium on Applied Computing, 1662-1665. https://doi.org/10.1145/3341105.3374126

Kitchenham, B., \& Charters, S. (2007). Guidelines for performing Systematic Literature Reviews in Software Engineering.

Koch, J., \& Schermuly, C. C. (2020). Who is attracted and why? How agile project management influences employee's attraction and commitment. International Journal of Managing Projects in Business, 14(3), 699-720. ABI/INFORM Collection. https://doi.org/10.1108/IJMPB-02-2020-0063

Kurniawan, R., Adler, H. M., Hamsal, M., \& Wibowo Kosasih. (2020). Orchestrating internal and external resources to achieve agility and performance: The centrality of market orientation. Benchmarking: An International Journal, 28(2), 517-555. ABI/INFORM Collection. https://doi.org/10.1108/BIJ05-2020-0229

Kurniawan, R., Budiastuti, D., Hamsal, M., \& Wibowo Kosasih. (2020). The impact of balanced agile project management on firm performance: The mediating role of market orientation and strategic agility. Review of International Business and Strategy, 30(4), 457-490. ABI/INFORM Collection. https://doi.org/10.1108/RIBS-03-2020-0022

Law, E. L.-C., \& Lárusdóttir, M. K. (2015). Whose Experience Do We Care About? Analysis of the Fitness of Scrum and Kanban to User Experience. International Journal of Human - Computer Interaction, 31(9), 584. ABI/INFORM Collection. https://doi.org/10.1080/10447318.2015.1065693

Lehnen, J., Schmidt, T. S., \& Herstatt, C. (2016). Bringing agile project management into lead user projects. International Journal of Product Development, 21(2-3), 212. ABI/INFORM Collection.

Lei, H., Ganjeizadeh, F., Jayachandran, P. K., \& Ozcan, P. (2017). A statistical analysis of the effects of Scrum and Kanban on software development projects. Robotics \& Computer-Integrated Manufacturing, 43, 59-67. EBSCO MegaFILE.

Lill, P. A., Wald, A., \& Gleich, R. (2020). AGILITY AND THE ROLE OF PROJECT - INTERNAL CONTROL SYSTEMS FOR INNOVATION PROJECT PERFORMANCE. International Journal of Innovation Management, 24(7). ABI/INFORM Collection. https://doi.org/10.1142/S1363919620500644 


\section{Issues in Information Systems}

Volume 22, Issue 3, pp. 278-295, 2021

Lindsjørn, Y., Sjøberg, D. I. K., Dingsøyr, T., Bergersen, G. R., \& Dybå, T. (2016). Teamwork quality and project success in software development: A survey of agile development teams. Journal of Systems \& Software, 122, 274-286.

Luong, T. T., Sivarajah Uthayasankar, \& Weerakkody Vishanth. (2021). Do Agile Managed Information Systems Projects Fail Due to a Lack of Emotional Intelligence? Information Systems Frontiers, 23(2), 415-433. ABI/INFORM Collection. https://doi.org/10.1007/s10796-019-09962-6

Marinho, M., Noll, J., Richardson, I., \& Beecham, S. (2019). Plan-Driven Approaches Are Alive and Kicking in Agile Global Software Development. 2019 ACM/IEEE International Symposium on Empirical Software Engineering and Measurement (ESEM), 1-11. https://doi.org/10.1109/ESEM.2019.8870168

Meding, W. (2017). Effective Monitoring of Progress of Agile Software Development Teams in Modern Software Companies: An Industrial Case Study. Proceedings of the 27th International Workshop on Software Measurement and 12th International Conference on Software Process and Product Measurement, 23-32. https://doi.org/10.1145/3143434.3143449

Mirzaei, M., \& Mabin, V. (2017). Agile Project Management and Public Policy Development Projects: A case study from New Zealand. New Zealand Journal of Applied Business Research (NZJABR), 15(1), 59-75. EBSCO MegaFILE.

Mishra, A., Sinha, K. K., \& Thirumalai, S. (2017). Project Quality: The Achilles Heel of Offshore Technology Projects? IEEE Transactions on Engineering Management, 64(3), 272-286. https://doi.org/10.1109/TEM.2017.2662021

Mkoba, E., \& Marnewick, C. (2020). Conceptual Framework for Auditing Agile Projects. IEEE Access, 8, 126460-126476. https://doi.org/10.1109/ACCESS.2020.3007874

Nerurkar, A., \& Das, I. (2017). Analysis of DILRMP Project: Identifying the Applicability of Agile Project Management for Digital Transformation Projects in Government and Public Sector. Proceedings of the Special Collection on EGovernment Innovations in India, 34-38. https://doi.org/10.1145/3055219.3055242

Noteboom, C., Ofori, M., Sutrave, K., \& El-Gayar, O. (2021). Agile Project Management: A Systematic Literature Review of Adoption Drivers and Critical Success Factors. Hawaii International Conference on System Sciences. https://doi.org/10.24251/HICSS.2021.813

Olteanu, C. G. (2018). IT Agile Transformation. Academy of Economic Studies. Economy Informatics, 18(1), 23-31. ABI/INFORM Collection.

Pareliya, M. (2019). IMPLEMENTING AGILE PROJECT MANAGEMENT (SCRUM) IN REAL ESTATE PROJECTS. Project Management Development - Practice \& Perspectives, 143-155.

Paterek, P. (2019). AGILE TRANSFORMATION CHANGES FROM THE PERSPECTIVE OF PROJECT TEAM VALUES. Project Management Development - Practice \& Perspectives, $162-$ 174. 


\section{Issues in Information Systems}

Volume 22, Issue 3, pp. 278-295, 2021

Perlak, J. (2019). Characteristics of Self-Organizing Teams in Agile Projcet Management: A Case Study. Acta Universitatis Nicolai Copernici. Nauki Humanistyczno-Spoleczne. Zarzadzanie, 46(1), 1927. ABI/INFORM Collection.

Pool, E. T., Poole, K., Upjohn, D. P., \& Hernandez, J. S. (2019). ‘AGILE’ HELPING MAYO IMPROVE ITS PROJECTS. Physician Leadership Journal, 6(2), 34. MasterFILE Premier.

Project Management Institute (Ed.). (2017a). A guide to the project management body of knowledge / Project Management Institute (Sixth edition). Project Management Institute.

Project Management Institute. (2017b). Achieving Greater Agility: The people and process drivers that accelerate results. Project Management Institute.

Project Management Institute, \& Agile Alliance (Eds.). (2017). Agile practice guide. Project Management Institute, Inc.

Salaou, A.-D., Damian, D., Lassenius, C., Voda, D., \& Gançarski, P. (2021). Archetypes of delay: An analysis of online developer conversations on delayed work items in IBM Jazz. Information \& Software Technology, 129, N.PAG.

Salman, A., Jaafar Mastura, Malik Summaira, Mohammad, D., \& Muhammad Sohail Ayaz. (2021). An Empirical Investigation of the Impact of the Communication and Employee Motivation on the Project Success Using Agile Framework and Its Effect on the Software Development Business. Business Perspectives and Research, 9(1), 46-61. ABI/INFORM Collection. https://doi.org/10.1177/2278533720902915

Sampietro, M. (2016). The adoption and evolution of agile practices. Project Management Development Practice \& Perspectives, 312-323.

Sanchez, F., Bonjour, E., Micaëlli, J.-P., \& Monticolo, D. (2019). A Step for Improving THE TRANSITION BETWEEN TRADITIONAL PROJECT MANAGEMENT TO AGILE PROJECT MANAGEMENT Using a Project Management Maturity Model. Journal of Modern Project Management, 7(1), 102-119.

Santana Furtado Soares, F., \& de Lemos Meira, S. R. (2015). An agile strategy for implementing CMMI project management practices in software organizations. 2015 10th Iberian Conference on Information Systems and Technologies (CISTI), 1-4. https://doi.org/10.1109/CISTI.2015.7170402

Şarlak, B. (2020). Agile Methodology for Project/Process Management IT System Infrastructure. 2020 11th International Conference on Computing, Communication and Networking Technologies (ICCCNT), 1-7. https://doi.org/10.1109/ICCCNT49239.2020.9225593

Schmitt, A., \& Hörner, S. (2021). Systematic literature review-improving business processes by implementing agile. Business Process Management Journal.

Schwaber, K., \& Sutherland, J. (2011). The Scrum Guide. Scrum Alliance, $21,19$.

Serrador, P., \& Pinto, J. K. (2015). Does Agile work? - A quantitative analysis of agile project success. International Journal of Project Management, 33(5), 1040. ABI/INFORM Collection. 


\section{Issues in Information Systems}

Volume 22, Issue 3, pp. 278-295, 2021

Shastri, Y., Hoda, R., \& Amor, R. (2021). The role of the project manager in agile software development projects. Journal of Systems \& Software, 173, N.PAG.

Shastri, Y., Hoda, R., \& Amor, R. (2017). Understanding the Roles of the Manager in Agile Project Management. Proceedings of the 10th Innovations in Software Engineering Conference, 45-55. https://doi.org/10.1145/3021460.3021465

Siddique, L., \& Hussein, B. (2019). Enablers and barriers to customer involvement in agile software projects in the Norwegian software industry: The Suppliers perspective. Journal of Modern Project Management, 7(2), 172-195.

Siddique, L., \& Hussein, B. A. (2016). GROUNDED THEORY STUDY OF THE CONTRACTING PROCESS IN AGILE PROJECTS IN NORWAY'S SOFTWARE INDUSTRY. Journal of Modern Project Management, 4(1), 52-63.

Sievi-Korte, O., Systä, K., \& Hjelsvold, R. (2015). Global vs. Local—Experiences from a distributed software project course using agile methodologies. 2015 IEEE Frontiers in Education Conference (FIE), 1-8. https://doi.org/10.1109/FIE.2015.7344101

Stormi, K. T., Laine, T., \& Korhonen, T. (2019). Agile performance measurement system development: An answer to the need for adaptability? Journal of Accounting \& Organizational Change, 15(2), 231256. ABI/INFORM Collection. https://doi.org/10.1108/JAOC-09-2017-0076

Tanner, M., \& Mackinnon, A. (2015). Sources of Interruptions Experienced During a Scrum Sprint. Electronic Journal of Information Systems Evaluation, 18(1), 3-18. ABI/INFORM Collection.

Taylor, K. J. (2016). Adopting Agile software development: The project manager experience. Information Technology \& People, 29(4), 670-687. ABI/INFORM Collection; Research Library. https://doi.org/10.1108/ITP-02-2014-0031

Thesing, T., Feldmann, C., \& Burchardt, M. (2021). Agile versus Waterfall Project Management: Decision Model for Selecting the Appropriate Approach to a Project. Procedia Computer Science, 181, 746756.

Thorgren, S., \& Caiman, E. (2019). The Role of Psychological Safety in Implementing Agile Methods across Cultures. Research Technology Management, 62(2), 31-39.

Vahanvati, M., \& Mulligan, M. (2017). A new model for effective post-disaster housing reconstruction: Lessons from Gujarat and Bihar in India. International Journal of Project Management, 35(5), 802-817. EBSCO MegaFILE.

Wells, H., Dalcher, D., \& Smyth, H. (2015). The Adoption of Agile Management Practices in a Traditional Project Environment: An IT/IS Case Study. 2015 48th Hawaii International Conference on System Sciences, 4446-4453. https://doi.org/10.1109/HICSS.2015.532

Wiboonrat, M. (2016). Applying agile to data center project. 2016 Management and Innovation Technology International Conference (MITicon), MIT-93-MIT-98. https://doi.org/10.1109/MITICON.2016.8025239

Zasa, F. P., Patrucco, A., \& Pellizzoni, E. (2021). Managing the Hybrid Organization: How Can Agile and Traditional Project Management Coexist?. Research Technology Management, 64(1), 54-63. 


\section{Issues in Information Systems}

Volume 22, Issue 3, pp. 278-295, 2021

Zhang, H., Huang, H., Shao, D., \& Huang, X. (2020). Fireteam: A Small-Team Development Practice in Industry. Proceedings of the 28th ACM Joint Meeting on European Software Engineering Conference and Symposium on the Foundations of Software Engineering, 1365-1375. https://doi.org/10.1145/3368089.3417068 